\title{
Aspectos econômicos da participação paulista no processo de independência
}

Economic Aspects of the

Paulista Engagement in the

Independence Process

\author{
Luiz Adriano Borges \\ Doutorando em História pela \\ Universidade Federal do Paraná \\ (UFPR - Curitiba/Brasil) \\ e-mail: adrianomad@gmail.com
}

\begin{abstract}
Resumo
0 presente artigo pretende analisar os interesses econômicos dos deputados paulistas enviados às Cortes Gerais Extraordinárias e Constituintes da Nação Portuguesa. Mais especificamente, busco perceber a acomodação entre seus interesses econômicos e as ideias políticas que pautavam suas reivindicações. A leitura dos discursos dos paulistas nos Diários nos coloca diante de três questões principais, todas já presentes nas Lembranças e apontamentos do Governo Provisório da Província de São Paulo: 1) a busca pela manutenção da unidade, mas exercida através de um poder executivo no Brasil; 2) a dúvida de qual seria o centro de poder na América Portuguesa; 3 ) o livre-comércio. Pretende-se demonstrar que esses pontos estão profundamente atrelados à formação socioeconômica e, em última instância, aos interesses econômicos destes deputados.
\end{abstract}

\begin{abstract}
The article analyzes the economic interests of the paulistas deputies sent to the Cortes Gerais Extraordinárias e Constituintes da Nação Portuguesa and how those questions were presented and ran at the meetings. In a second moment, I intend to look at the accommodation between their economic interests and the political ideas that were in their requests. The reading of the paulistas speeches in the Diaries raises three main points:

1) the search for keeping the unity through Brazil's executive power;

2) doubts on the location of the central power in the Portuguese America;

3) free trade. It is attempted to show that these point are deeply connected to the socio-economic formation, and to the last instance, to the economic interests of those deputies.
\end{abstract}

Palavras-chave

mercado interno, federalismo, Cortes de Lisboa

Keywords

internal market, federalism, Lisbon Courts 
Os Diários das Cortes se encontram online: http:// debates.parlamento.pt/catalog.aspx?cid=mc.c1821. Foi englobado nesta pesquisa, o período de 5 de fevereiro a 6 de outubro, que cobre a participação paulista nas Cortes.

2

MARSON, Izabel; OLIVEIRA, Cecilia Helena L. de Salles (orgs.). Monarquia, Liberalismo e Negócios no Brasil: 1780-1860. São Paulo: Edusp, 2013. p.29.

3

Ver mais sobre este assunto em DUMONT, Louis. Homo hierarchicus. 0 sistema de castas e suas implicações. São Paulo: Unesp, 1992. p.222-224. FRANCO, Maria Sylvia de Carvalho. Homens livres na ordem escravocrata. São Paulo: Unesp, 1997, especialmente cap. 3, 0 homem comum, a administração e o Estado; MARSON, Izabel Andrade. 0 império do progresso. A revolução praieira. São Paulo: Brasiliense, 1987, p.261-262.

4

LUNA, Francisco Vidal; KLEIN, Herbert S. Evolução da sociedade e economia escravista de São Paulo, de 1750 a 1850. São Paulo: Edusp, 2006. p.26-27.

5

PETRONE, Maria Thereza Schorer. 0 desprezado "ciclo do açúcar" paulista (1765-1850). IN: ODALIA, Nilo; CALDEIRA, João Ricardo de Castro (orgs). História do Estado de São Paulo: a formação da unidade paulista. Vol. 1 Colônia e Império. São Paulo: Unesp; Arquivo Publico do Estado; Imprensa Oficial, 2010. FERLINI, Vera Lucia Amaral. Uma capitania dos novos tempos: economia, sociedade e política na São Paulo restaurada (1765-1822). Anais do Museu Paulista, v.17, n.2, p.237-250, Julho-dezembro, 2009.

6

LUNA, Francisco Vidal; KLEIN, Hebert. Op. Cit., cap.2.
Um olhar mais demorado e atento para os Diários das Cortes 1 nos mostra que a investigação desses registros é fundamental para compreender o processo de "desmembramento" de Portugal, não sendo suficiente, no entanto, para apreender tudo o que estava por trás das ideias defendidas na ocasião. Para analisar os interesses econômicos dos deputados paulistas enviados às Cortes Gerais Extraordinárias e Constituintes da Nação Portuguesa é necessário, também, voltar-se para sua formação socioeconômica. Assim, através dessas duas frentes de análise (as falas paulistas nas Cortes e a formação socioeconômica destes deputados), pretendo demonstrar que os pontos apresentados e defendidos pelos deputados paulistas nas Cortes estavam intimamente ligados a seus interesses econômicos. Costurando desta maneira os diversos discursos esparsos, espero possibilitar uma maior compreensão ao processo de construção do Estado nacional a partir da Independência brasileira.

A imbricação existente entre política e economia constitui dimensão fundamental para as bases metodológicas deste texto. Para o contexto historiográfico brasileiro, um conjunto de textos recentes sobre essa temática foi reunido no livro Monarquia, Liberalismo e Negócios no Brasil, que buscou explicitar "como a disputa entre grupos pelo exercício do poder - frequente matriz das revoluções - resguardava o interesse pelos lucrativos negócios gerenciados por aqueles que comandassem o governo."2 Essa especificidade da sobreposição entre o político e o econômico estava presente nas ações e discursos dos indivíduos do século XIX, e transparece na participação dos deputados nas Cortes de Lisboa. ${ }^{3}$ Antes de avançarmos propriamente para os debates nas Cortes e seus desdobramentos políticos, faz-se necessário, portanto, avaliar o contexto econômico da região de São Paulo no período anterior à convocação da Assembleia em Lisboa.

Durante muito tempo, a capitania e depois província de São Paulo nas primeiras décadas do século XIX, foi vista pela historiografia como uma região secundária se comparada às outras regiões do Centro-Sul e do Nordeste. Desde início do século XVIII, São Paulo vinha se tornando um centro dinâmico de produção açucareira e se consolidou como centro econômico e político da colônia, após a abertura das minas de ouro em Minas Gerais. Por sua vez, esta capitania, sem produtos de exportação, baseava sua economia na agricultura de abastecimento e na pecuária. ${ }^{4}$

A estrutura econômica da capitania de São Paulo nas três décadas que antecederam a Independência tinha como base o comércio do binômio mulas-açúcar. Este se estabeleceu no Oeste Paulista a partir da segunda metade do século XVIII, sendo as vilas de Sorocaba, Mogi Guaçu, Jundiaí e Piracicaba, as principais exportadoras deste produto no fim do setecentos, formando o chamado "quadrilátero do açúcar". ${ }^{5}$ A crescente produção de açúcar era enviada ao porto do Rio de Janeiro, através de Santos, para posterior embarque para a Europa. ${ }^{6} 0$ açúcar foi um agente dinamizador do comércio na capitania e também favoreceu o comércio interprovincial, o que, por sua vez, levou a uma ampliação da estrutura viária por onde era escoado o produto no lombo de mulas.

0 negócio de animais que movimentava as estradas do Sul teve início com o ciclo da mineração nas Minas Gerais e continuou com as necessidades da região Centro-Sul do Brasil. Necessidades que eram múltiplas: de vestimentas, alimentação e, principalmente, transporte, as quais eram supridas, respectivamente, pelo couro, carne vacum e muares do Rio Grande do Sul. 0 montante do negócio de animais tendeu a au- 
GIL, Tiago Luis. Coisas do caminho. Tropeiros e negócios do Viamão à Sorocaba (1780-1810). Tese (Doutorado em História). Universidade Federal do Rio de Janeiro, Rio de Janeiro, 2009; KLEIN, Herbert S. A oferta de muares no Brasil central: o mercado de Sorocaba, 1825-1880. Estudos Econômicos, v.19, n.2, mai-ago/1989; PETRONE, Maria Thereza Schorer. O Barão de Iguape. Um empresário da época da independência. São Paulo: Ed. Nacional; Brasilia: Instituto Nacional do Livro, 1976; SUPRINYAK, Carlos Eduardo. Comércio de animais de carga no Brasil Imperial: uma análise quantitativa das tropas negociadas nas provincias do Paraná e São Paulo. Dissertação (Mestrado em Economia). Universidade Estadual Paulista "Júlio de Mesquita Filho". São Paulo, 2006.

8

BRUNO, Ernani Silva. História e tradições da cidade de São Paulo. Rio de Janeiro: José Olímpio, 1953; MORSE, Richard M. Formação histórica de São Paulo. Difel, 1970; TAUNAY, Afonso de E. Historia da cidade de São Paulo. São Paulo: Melhoramentos, 1953.

9

MATTOS, Renato de. Política, administração e negócios: a capitania de São Paulo e sua inserção nas relações mercantis do Império Português (1788-1808). Dissertação (Mestrado em História) Universidade de São Paulo, São Paulo, 2009, especialmente capitulo 1; SIMONSEN, Roberto C. História econômica do Brasil (1500-1800). São Paulo: Companhia Editora Nacional, 1962. É também o caso de estudos para Minas Gerais. Ver estudos de GRAÇA FILHO, Afonso de Alencastro. A princesa do oeste e $O$ mito da decadência de Minas Gerais. São João Del Rei (1831-1888). São Paulo: Annablume, 2002; BERGAD, Laird W. Escravidão e história econômica: demografia de Minas Gerais, 1720-1880. Bauru: Edusc, 2004, e extensa bibliografia ali citada.

10

MARCILIO, Maria Luiza. Crescimento demográfico e evolução agrária paulista - 1700-1836. São Paulo: Edusp-HUCITE, 2000. p.190-193.

11

0 trabalho de Araújo serve como um primeiro passo aos estudos sobre a riqueza da província de São Paulo no século XIX, já que a autora trabalhou de maneira bastante circunscrita, utilizando somente inventários de moradores do núcleo central da cidade de São Paulo. Além disso, pela própria especificidade dos documentos utilizados, o que se apresenta é a riqueza detida na hora da morte do inventariado, perdendo assim detalhes da trajetória da riqueza do indivíduo ao longo da vida. Mais pesquisas neste sentido precisam ser feitas. ARAÚJO, Maria Lucília Viveiros. Os caminhos da riqueza dos Paulistanos na primeira metade do oitocentos. São Paulo, Hucitec-Fapesp, 2003.

12

LUNA, Francisco Vidal; KLEIN, Hebert S. Op. Cit, p.252. 13

FRAGOSO, João Luis. Homens de grossa aventura: 1790-1830. Rio de Janeiro: Civilização brasileira, 1998. p.135.

14

Ibidem, p.135-136.

15

Ibidem, p.146. mentar ao longo da primeira metade do século XIX, principalmente com a vinda da família real para o Rio de Janeiro e com a posterior fixação da capital do império brasileiro na província fluminense. Mas desde o final do século XVIII, muitos negociantes paulistas vinham investindo neste negócio. Todo o processo de compra e venda podia durar meses e até um ano, e requeriam um grande capital inicial. Os animais eram comprados em Viamão, Rio Grande do Sul, e trazidos até Sorocaba, onde eram vendidos em uma feira anual, para então serem redistribuídos para outras regiões, principalmente para a Corte. ${ }^{7}$

Muitos negociantes enriqueceram investindo na cultura do açúcar e no negócio de animais, alguns nas duas atividades ao mesmo tempo. Podem ser citados aqui, Antonio da Silva Prado, Nicolau Pereira de Campos Vergueiro e o Brigadeiro Luis Antonio de Souza Queiróz. Apesar de possuir grandes negociantes, a província/capitania de São Paulo foi avaliada durante muito tempo pela historiografia como uma região bastante empobrecida, ${ }^{8}$ relacionando-se sua decadência com o declínio da mineração nas Gerais.

Porém, amparados em ampla gama de fontes, trabalhos recentes têm demonstrado uma outra faceta ${ }^{9}$. Maria Luíza Marcílio criticou a visão da "decadência", uma vez que o "aumento extraordinário e continuado da população regional em todo o século XVIII", além do ingresso de uma economia empresarial e capitalista de exportação de produtos tropicais, abriu novos mercados para o abastecimento e possibilitou a organização da economia paulista, sem a qual o café não teria se desenvolvido. ${ }^{10}$

Maria Lucília Viveiros Araújo, trabalhando com inventários postmortem da cidade de São Paulo para a primeira metade do século XIX, encontrou ali indivíduos tão ricos quanto aqueles que residiam no Rio de Janeiro, a região mais rica do período. ${ }^{11}$ Francisco Vidal Luna e Herbert Klein perceberam que foi no final do século XVIII e início do XIX que se estabeleceu "uma dinâmica classe de agricultores, de um mercado complexo e de uma rede de transportes mais moderna, tudo isso aparecendo (...) antes da ascensão do café."12

Utilizando também fontes quantitativas, tais como inventários, João Fragoso traz mais dados para corroborar esse crescimento. Segundo o autor, baseado em dados de Elizabeth Kuznetsof

o crescimento estaria ligado, por um lado, à introdução e aumento da agroexportação no território paulista, gerando uma maior demanda por alimentos e, por outro lado, à manutenção de um comércio intercolonial, em especial o Rio de Janeiro. ${ }^{13}$

Fragoso ainda percebe um fluxo de comércio interno entre São Paulo e as regiões do Sudeste, capitaneado pelo açúcar e o negócio de animais. ${ }^{14}$ Para estas duas atividades era necessário um mercado consumidor, o que acaba ocorrendo nas diversas regiões do centro-sul. ${ }^{15}$

Como se verifica, esse mercado complexo estabeleceu relações com outras praças mercantis na América Portuguesa, como o Rio de Janeiro, que recebia o açúcar e os animais do sul. Deste modo, São Paulo desempenhava, em parte, uma "economia de passagem" que, segundo Wilma Peres Costa, ajuda a explicar o compromisso desta capitania com o Rio de Janeiro, já que a economia paulista havia se ampliado com a vinda da Corte e era favorecida pela proximidade com o centro político. Soma-se a isto o fato de que o aumento no trânsito de animais destinados à corte trouxe 
BADDINI, Cassia Maria. Sorocaba no Império: comércio de animais e desenvolvimento urbano. São Paulo: Fapesp: Annablume, 2002, p.58; COSTA, Wilma Peres. Do domínio à Nação: os impasses da fiscalidade no processo de independência. IN: JANCSÓ, István. Brasil: formação do Estado e da Nação. São Paulo: Hucitec/ Fapesp, 2003. p.177; DANIELI, Maria Isabel Basilisco Celia. Economia mercantil de abastecimento e rede tributária: São Paulo, séculos XVIII e XIX. Tese (Doutorado em História) Universidade Estadual de Campinas, Campinas, 2006, especialmente cap.5.

17

DIAS, Maria Odila Leite da Silva. A interiorização da metrópole (1808-1853). In: MOTA, Carlos Guilherme (org.) 1822: Dimensões. São Paulo: Perspectiva, 1982

18

LENHARO, Alcir. As tropas da moderação. 0 abastecimento da Corte na formação política do Brasil, 1802-1842. São Paulo: Ed. Símbolo, 1979. p.24

19

Ibidem, p.23-29.

20

PETRONE, Maria Thereza Schorer. 0 desprezado "ciclo do açúcar" paulista..., Op. Cit.

21

OLIVEIRA, Cecilia Helena de Salles. A astúcio liberal: relações de mercado e projetos políticos no Rio de Janeiro (1820-1824). Bragança Paulista: Edusf/ Ícone, 1999.

22

Idem. Imbricações entre política e interesses econômicos. A complexa definição dos fundamentos da monarquia no Brasil da década de 1820. Anais do V Congresso Brasileiro de História Econômica e 6a. Conferência Internacional de História de Empresas, Caxambu. Associação Brasileira de pesquisadores em História Econômica, 2003. Vol.1; Idem. A província de São Paulo à época da Independência. IN: ODALIA, Nilo; CALDEIRA, João Ricardo de Castro (orgs). Op. Cit.

23

BLAJ, Ilana. A trama das tensões. 0 processo de mercantização de São Paulo Colonial (1681/1721). São Paulo: Humanitas/USP/Fapesp, 2002; BORREGO, Maria Aparecida Menezes. A teia mercantil: negócios e poderes em São Paulo colonial. Tese (Doutorado em História). Universidade de São Paulo, Faculdade de Filosofia, Letras e Ciências Humanas, São Paulo, 2006; MEDICCl, Ana Paula. Entre a "decadência" e o "florescimento": a capitania de São Paulo na interpretação de memorialistas e autoridades públicas (1782/1822). Dissertação (Mestrado em História), Universidade de São Paulo, Faculdade de Filosofia, Letras e Ciências Humanas, São Paulo, 2005; Idem. Administrando conflitos: 0 exercício do poder e os interesses mercantis na capitania/província de São Paulo (1765-1822). Tese (Doutorado em História), Universidade de São Paulo, Faculdade de Filosofia, Letras e Ciências Humanas, São Paulo, 2010. um incremento nos impostos sobre animais, transformando estas taxas nos principais rendimentos da província paulista. ${ }^{16}$

A transferência da corte para o Brasil estreitou os laços com a capitania carioca ainda mais. Este é um ponto fundamental para se compreender a relação entre economia e política neste período. Uma das primeiras abordagens que combinou a relação entre economia e política é a de Maria Odila Leite da Silva, no texto "A interiorização da metrópole". Neste artigo, a autora fixa 1808 como um ponto de mudança no processo de ruptura do Brasil com Portugal e também como um início de enraizamento dos interesses mercantis portugueses no centro-sul. 0 texto demonstra a profunda inter-relação de fatores econômicos com políticos, voltando-se para as redes de abastecimento que integravam o Rio de Janeiro com outras regiões e que estavam conectadas com as mudanças políticas que vinham sendo introduzidas com a chegada da Corte portuguesa. ${ }^{17}$

0 trabalho Tropas da moderação, de Alcir Lenharo, publicado em 1979 e orientado por esta autora, levou adiante essa argumentação. Nele, o autor, trata do mercado de abastecimento do Rio de Janeiro tendo como atores principais os negociantes de animais. 0 próprio subtítulo da obra já revela esta tentativa de aproximar economia e política imperial: "o abastecimento da Corte na formação política do Brasil (1808-1842)". A escolha tem o objetivo de demonstrar como indivíduos ligados ao mercado abastecedor do centro-sul se articularam em âmbito regional e se projetaram no centro político através da prática mercantil. ${ }^{18}$ As conexões comerciais de negociantes de animais e açúcar com o mercado do Rio de Janeiro fez com que eles obtivessem uma crescente influência política. ${ }^{19}$ Maria Thereza Petrone já havia apontado a importância da região fluminense como conectora das diversas rotas de tropeiros, principalmente após a chegada da família real em $1808 .^{20}$

Mais recentemente, Cecilia Helena de Salles Oliveira tem buscado articular o político e o econômico, desde sua tese "A astúcia liberal"21, ao lado de outros estudos publicados em artigos ${ }^{22}$. Nestes trabalhos, a autora retoma ideias de Maria Odila Leite da Silva Dias e Alcir Lenharo, e atenta especialmente para as ligações políticas e econômicas do centro-sul. Para ela, a convergência de políticos de São Paulo em torno da defesa do Rio de Janeiro como centro do novo Estado após a independência esteve ligada às sólidas ligações mercantis estabelecidas entre as duas capitanias desde 1808.

Cabe também citar recentes estudos que apontam São Paulo como centro de convergência de rotas comerciais que cortavam a América Portuguesa e ligavam negociantes paulistas aos mercados do Rio de Janeiro, Minas Gerais e Goiás, já em meados do século XVIII. É o caso dos trabalhos de Ilana Blaj, Maria Aparecida de Menezes Borrego e Ana Paula Medicci. ${ }^{23}$

\section{A organização administrativa e econômica durante o Governo Provisório da província de São Paulo}

A Revolução Liberal do Porto teve início em agosto de 1820, rapidamente se convocando as "Cortes Gerais e extraordinárias da Nação Portuguesa" para compor uma nova constituição para o Império. Os liberais portugueses estavam bastante influenciados pelo liberalismo espanhol, que desde as Cortes de Cádiz (1810-1814) e as Cortes Espanholas de Madri (1820), vinham propondo uma Constituição Liberal afirmando a soberania da nação, tanto europeia quanto americana. Foi exatamente a retomada das Cortes Espanholas em abril de 1820, anteriormente suspensas por Fernando 
BERBEL, Márcia Regina. A constituição espanhola no mundo luso-americano (18201823). Revista das Índias, v. LXVIII, n. 242, p. 225-254, 2008

25

Idem. A nação como artefato. Deputados do Brasil nas Cortes portuguesas (1821-1822). São Paulo: Hucitec/Fapesp, 1999. p.49.

26

LEME, Marisa Saenz. A construção do poder de governo na província de São Paulo e o Estado em formação no Brasil independente: entre a Revolução do Porto e a outorga constitucional. Op. Cit., p.373.

27

DELATORRE, Aparecida Vanessa. São Paulo à época da independência. Contribuição para o estudo do movimento da "bernarda", 1821/1823. Dissertação (Mestrado em História). Universidade de São Paulo, Faculdade de Filosofia, Letras e Ciências Humanas, São Paulo, 2004

28

Atas da Câmara de São Paulo, 23 de junho de 1821.

LEME, Marisa Saenz. Op. Cit., p.378.

30

DELATORRE, Aparecida Vanessa. Op. Cit.
VII, que levou os portugueses a fazerem o mesmo em solo lusitano. Deste modo, as sugestões para a "Carta da Nação" que se pretendia para Portugal possuiam forte cunho liberal espanhol. ${ }^{24}$

Da mesma maneira que o Império Espanhol vinha sofrendo um processo de desintregação, devido a reivindicações autonomistas por parte dos americanos, Portugal atravessava uma crise gerada pela transferência da Corte portuguesa para o Rio de Janeiro. Após o fim das guerras napoleônicas, a recusa de Dom João de retornar a Lisboa foi a gota d'água no caldeirão de insatisfação dos portugueses, culminando na articulação da Revolução do Porto.

Após convocação e início das atividades das Cortes em janeiro de 1821, instruções sobre a forma de eleição de representantes foram elaboradas. Seguindo definições de Cádiz, a província era a última instância no processo de escolha dos deputados. ${ }^{25}$ Assim, as províncias da porção europeia do Império Português e as americanas passaram a providenciar a eleição de deputados.

Com o intuito de iniciar o processo eleitoral, realizou-se uma transformação na estrutura dos governos provinciais no Brasil. Em São Paulo, a formação da Junta de Governo da Província se deu em 23 de junho de 1821. É interessante perceber o que Marisa Saenz Leme aponta acerca d a formação destas Juntas no Brasil: as revolucionárias - "no sentido de Juntas formadas à revelia da Corte do Rio de Janeiro" - e as oficiosas - "no sentido de Juntas formadas já com o aval e o direcionamento emanados do Rio de Janeiro". Neste segundo caso se encaixam as Juntas formadas na Bahia, Pará e Pernambuco. Já Minas Gerais e São Paulo estiveram gravitando em torno da província fluminense. ${ }^{26}$ Isto é um dado importante na análise que se segue, apontando para a confluência de interesses entre as três províncias.

A demora na instalação da Junta paulista em relação a outras juntas foi ocasionada pelos conflitos existentes entre os grupos opositores da localidade. ${ }^{27}$ De qualquer forma, a Junta paulista foi escolhida por aclamação e não por procedimento eleitoral, num ajuntamento dos "vereadores, povo e tropa" em frente à Câmara de São Paulo. ${ }^{28}$ Como aponta Leme, apoiada na historiografia, "o modo por que a Junta paulista se constituiu indica uma solução de compromisso entre forças que se opunham na província, tendo por base disputas econômicas que se expressavam também em diferentes matizações políticas." ${ }^{29}$ De um lado, estavam os membros das familias antigas que compunham a sociedade desde o século XVII, residindo na capital e em torno. De outro lado, o grupo era formado por setores sociais mais recentes, ligados ao cultivo da cana de açúcar em Itu e região e aproveitando-se do desenvolvimento do porto de Santos, utilizando-o como ponto de saída de produtos de exportação da capitania. ${ }^{30}$

Como não houve uma regulamentação que indicasse a forma de composição da Junta, optou-se por esta solução de compromisso entre forças representantes opositoras, tendo José Bonifácio a função de indicar 15 membros que dela fariam parte. Cabe apontar alguns nomes que se destacaram na conjuntura dos meses seguintes: para presidente, João Carlos Augusto d'Oyenhausen, e para vice-presidente o próprio José Bonifácio; para secretário do Governo do Interior e da Fazenda, Martim Francisco de Andrada e Silva, irmão de Bonifácio; para a pasta da "Agricultura", Nicolau Pereira de Campos Vergueiro e; para "Comércio", Francisco Ignácio de Souza Queiroz e Manuel Rodrigues Jordão. 
31

LEME, Mariza Saenz. Op. Cit., p.381

32

OLIVEIRA. Cecília Helena de Salles. A província de São Paulo... Op. Cit., p.346-347.

33

LEME, Marisa Saenz. Op. Cit., p.385.

34

AMARAL, Brenno Ferraz do. José Bonifácio. São Paulo: Martins, 1961. p.94-95, apud: BERBEL, Márcia Regina. A nação como artefato... Op. Cit., p.74.

35

CALDEIRA, Jorge. José Bonifácio de Andrada e Silva. São Paulo, Editora 34, 2002. p.125-133.

36

FORJAZ, Djalma. O Senador Vergueiro. Sua vida e sua época (1778-1859). São Paulo, Oficinas do Diário Oficial, 1924. p.208-209.
Como bem salientou Leme, pela pasta do "Comércio", estes dois últimos nomes representavam diferentes segmentos das elites socioeconômicas e compunham o quadro de antigos e novos setores sociais que disputavam o poder na província entre si. Souza Queiroz era relacionado aos setores mais tradicionais, sendo considerado um negociante de grosso trato. Jordão, por sua vez, ligava-se, assim como os irmãos Andrada, às atividades mais recentes, desenvolvidas em Santos e em áreas do interior. ${ }^{31}$

Apesar do barril de pólvora que era a composição da Junta, a atuação conciliatória de José Bonifácio, envolvendo setores poderosos, mas diversos, evitou um confronto armado. Mesmo assim continuaram a haver divergências entre os membros da Junta. De acordo com Cecília Helena de Salles Oliveira, estas divergências decorriam do fato de tais grupos terem ideias diferentes com relação ao controle das arrematações e de fatias do mercado de abastecimento, e de apresentarem interpretações variadas acerca de práticas mercantis e administrativas a serem adotadas, o que acabava por conduzir a debates sobre possiveis relações com as Cortes em Lisboa e/ou com o governo no Rio de Janeiro. ${ }^{32}$

A relação de São Paulo com o Rio de Janeiro era bem próxima, entretanto ainda não se sinalizava total dependência política e administrativa com a Corte. Um exemplo disso é a questão financeira, na qual a Junta preconizava uma autonomia sobre questões econômicas. ${ }^{33}$ Márcia Regina Berbel ressalta que o apoio de São Paulo estava condicionado à questão de autonomia da Junta provincial:

a) livre disposição do governo interior; b) livre gestão da economia provincial (negativa à remessa de fundos para o Erário, na Corte); c) direito de representação contra execuções de leis e decretos, contrários às peculiaridades e circunstâncias locais, a juizo da Junta. ${ }^{34}$

Seria somente nos meses seguintes à formação da junta, em junho de 1821, que a aproximação com a província fluminense ficaria mais intensa.

De qualquer forma, a Junta procurou proceder à elaboração de "memórias e representações" sobre diversos aspectos da província e também de instruções para os deputados paulistas às Cortes de Lisboa, chamada de Lembranças e apontamentos do Governo Provisório da Província de São Paulo para os seus deputados. ${ }^{35}$ Este documento era exclusivo dos deputados paulistas, trazendo instruções recolhidas em várias câmaras na província e, como veremos à frente, mostrava a visão dos paulistas na relação metrópole-colônia.

Além disso, a Junta organizou a eleição dos deputados paulistas que seriam enviados às Cortes. Desta forma, seguindo as definições de Cádiz, a província passou a ser a última instância (de três níveis: freguesias, comarcas e províncias), para a escolha dos deputados. Em São Paulo, o processo final após votação nas outras instâncias, ocorreu com 18 eleitores se deslocando para a capital paulista, que representavam a elite política e econômica de toda a região da província. ${ }^{36} \mathrm{~A}$ lista dos eleitores e passiveis de serem votados ficou assim determinada: da comarca de São Paulo: José Bonifácio de Andrada e Silva, Martim Francisco Ribeiro de Andrada, Felisberto Gomes Jardim, João Ferreira de 0. Bueno, Padre Félix José de Oliveira, André da Silva Gomes; da comarca de Itu: Nicolau Pereira de Campos Vergueiro, Rafael Tobias de Aguiar, Padre Diogo Antonio Feijó, Francisco de Paula Souza e Mello, Antonio Paes de Barros, José de Almeida Leme e seus substitutos, Bento Paes de Barros e José Martins 
37

Outros eleitos como substitutos foram: Antonio Manoel da Silva Bueno e Antonio Paes de Barros.

38

LEME, Marisa Saenz. Op. Cit., p.390.

39

WERNET, Augustin. 0 processo de independência em São Paulo. IN: MOTA, Carlos Guilherme. (org). 1822... Op. Cit., p.345-346.

40

Uma das únicas comarcas que apoiaram os "bernardista" foi a de Curitiba, através da figura do Coronel Antonio Joaquim da Costa Gavião, que era aparentado do Brigadeiro bernardista Joaquim José Pinto de Moraes Leme. DAMACENO, Daniel Tarifa. Os "facciosos" de São Paulo. (considerações acerca da Bernarda de Francisco Inácio, 23.05.1822-25.08.1822). Dissertação (Mestrado em História). Universidade de São Paulo, Faculdade de Filosofia, Letras e Ciências Humanas, São Paulo, 1993. p.165.

41

LEME, Marisa Saenz. Op. Cit. p.390-96. da Costa Passos; da comarca de Paranaguá e Curitiba: Reverendo Antonio Teixeira Camelo, João da Silva Machado, João Carneiro Lobo e como substituto: Antonio José Pereira Branco. Estes eleitores resumiam a nata econômica e política da vasta província paulista e votariam em nomes dentre eles que representariam a província.

Em 9 de maio de 1821 foram eleitos e mandados a Lisboa, entre outros, Antonio Carlos de Andrada e Silva, o Andrada mais novo, José Ricardo da Costa Aguiar, Francisco de Paula Souza e Mello, Nicolau Pereira Campos Vergueiro, José Feliciano Fernandes Pinheiro e o padre Diogo Antonio Feijó. ${ }^{37}$

Antes de avançar para uma visualização das trajetórias desses indivíduos, devemos olhar para algo que aconteceu em São Paulo logo após a chegada dos paulistas em Lisboa. Em maio de 1822 ocorreu um movimento armado que sinalizou o auge das insatisfações provinciais e que gerou uma articulação com a Corte de D. Pedro. Esse movimento, conhecido como "Bernarda", foi um levantamento em armas que resultou na reestruturação da Junta. A "Bernarda" de Francisco Inácio, ocorrida em maio de 1822 é sintomática para perceber a formação de forças políticas opostas em São Paulo. A disputa envolveu, de um lado, os Andradas, mais especificamente os irmãos José Bonifácio e Martim Francisco e seus aliados e, de outro, Francisco Inácio de Souza Queiróz e João Carlos de Augusto Oeynhausen. Um dos motivos da revolta foi "o despotismo dos Andradas".

De acordo com Leme, as tensões do Governo Provisório administrado pela Junta "tiveram sua dimensão mais explosiva nas questões da comercialização da carne verde e da cobrança de impostos, internamente realizados na província." ${ }^{138}$ Esses assuntos passavam pela questão do abastecimento interno, já que os dízimos recaíam sobre a produção e comercialização de produtos agrários e da pecuária. Foi um elemento bastante importante nesses meses de definição do Estado Nacional, pois envolvia negociantes com grandes interesses na província, e que também possuiam ligações na Corte. A Bernarda teria sido, assim, para além de atritos pessoais, um reflexo da luta de interesses comerciais.

Para esse período, Augustin Wernet ${ }^{39}$ dividiu os grupos dominantes em São Paulo em: 1) "homens de horizontes muito amplos e de interesses cosmopolitas" como José Bonifácio, Martim Francisco e Nicolau Vergueiro; 2) um grupo formado no interior da capitania "gente de Itu, Porto Feliz e São Carlos, proprietários de grandes canaviais e senhores de numerosa escravaria" entre os quais Francisco de Paula Souza e Mello, Antonio Paes de Barros e Manuel Rodrigues Jordão; 3) homens da "antiga administração que defendiam ideias da época ou continuavam no cenário político por motivos de prudência de outros grupos políticos e militares", representados por Oeynhausen, Oliveira Pinto, Francisco Inacio e Costa Carvalho. Estes últimos, todos rebeldes na Bernarda.

Em maio de 1822, o governador-geral Oyenhausen, Costa Carvalho e Francisco Inácio foram chamados ao Rio de Janeiro, com a determinação de se explicarem sobre desobediências da Junta, mas a ordem servia ao mesmo tempo como desculpa para que Martim Francisco assumisse a presidência da província, com a vacância do cargo. Desta forma, instigados por Francisco Ignácio, "a tropa e o povo" se manifestaram, forçando um pedido de demissão de Martim Francisco e Manoel Jordão, que acabaram sendo expulsos da capital. ${ }^{40}$ Uma nova Junta continuou as atividades, que só foi desfeita com a vinda de D. Pedro para São Paulo em agosto, atuando como príncipe regente. ${ }^{41}$ 
SILVA, Maria Beatriz Nizza da (org.). História de São Paulo colonial. São Paulo: Editora da Unesp, 2009, cap. 4 - São Paulo e a independência, p.305.

43

DAMACENO, Daniel Tarifa. Op. Cit. p.244; HORNER, Erik. Em defesa da constituição: a guerra entre rebeldes e governistas. Tese (doutorado em História). Universidade de São Paulo, Faculdade de Filosofia, Letras e Ciências Humanas, São Paulo, 2010.

44

OLIVEIRA, Cecilia Helena de Salles. A província de São Paulo... Op. Cit., p. 350; MEDICCI, Ana Paula. Op. Cit., p. 222; DAMACENO, Daniel Tarifa. Op. Cit.

45

BORREG0, Maria Aparecida de Menezes. Laços familiares e aspectos materiais na dinâmica mercantil na cidade de São Paulo (séculos XVIII e XIX). Anais do Museu Paulista. São Paulo, v. 18, n. 1, p.11-41.

46

MEDICCI, Ana Paula. Administrando conflitos... Op. Cit., p.223-224.

47

Ibidem, p.189.

48

FORJAZ, Djalma. Op. Cit.
Francisco Inácio era natural de São Paulo e enriqueceu atuando como comerciante. Foi casado com uma prima sua, D. Francisca Miquelina, filha do brigadeiro Luis Antonio de Souza e de D. Genebra de Barros Leite. Esta era irmã de Antonio Paes de Barros; Genebra, por sua vez, após enviuvar casou-se com José da Costa Carvalho. Francisco Inácio estava, portanto, inserido em uma teia de relações pessoais que serviam de base política na província. ${ }^{42}$

Os rebeldes "bernardistas" foram deportados para outras províncias, mas alguns, mesmo após terem sido condenados, conseguiram retornar à vida pública. Foi o caso de Costa Carvalho, que foi considerado um dos principais cabeças no movimento, mas assumiu uma vaga na Regência Trina permanente em 1831. Em 1842 seria presidente da província de São Paulo. ${ }^{43}$

As interpretações para a "Bernarda" apontam para os interesses econômicos e políticos divergentes dos grupos paulistas que estavam preocupados com o papel que desempenhariam com relação ao Rio de Janeiro, pensando em uma ampliação de sua influência no mercado carioca e na política da Corte..$^{44}$

Para se ter ideia das profundas relações comerciais e familiares envolvidas nos conflitos em São Paulo pode-se citar o grupo capitaneado por Martim Francisco, apoiados por negociantes como Antonio da Silva Prado e seu tio Manoel Jordão, ocupante do cargo de tesoureiro na Junta da Fazenda do governo provisório. ${ }^{45}$ Outro exemplo, do lado oposto, é o grupo liderado por Francisco Ignácio de Souza Queiroz, herdeiro do brigadeiro Luis Antonio. ${ }^{46} \mathrm{E}$ de fato, a união desses grupos só foi consolidada após a vinda do príncipe regente para a província.

Mas aqueles que foram para as Cortes de Lisboa, na qualidade de deputados por São Paulo, também possuiam origens sócio-econômicas que nos ajudam a compreender sua atuação. Para além de mostrar uma pequena biografia de cada um dos deputados brasileiros, apresento de maneira sucinta a trajetória econômica e política dos paulistas enviados às Cortes tendo em vista a situação provincial, já que isto influencia nos seus posicionamentos em Lisboa. Opto por analisar a trajetória de Vergueiro, Feijó e Antonio Carlos, por serem os três paulistas que realizaram discursos significativos nas Cortes.

Nicolau Pereira de Campos Vergueiro nasceu em Portugal em 1778, chegou ao Brasil em 1803, e logo deu início a sua vida pública como advogado. Através de sua trajetória administrativa foi tendo contato com negociantes de gado e proprietários de terras de São Paulo. Em 1806 desempenhou a função de promotor de resíduos, sendo encarregado de avaliar a prestação de contas de testamentos; em 1809, superintendente da cobrança da décima urbana ${ }^{47}$; de 1811 a 1818 foi juiz de sesmarias; em 1811 foi juiz ordinário; em 1813, vereador; em 1820 foi inspetor das estradas de Piracicaba ${ }^{48}$. Estes cargos também o ajudariam a ser um dos indicados como deputado às Cortes de Lisboa. Desde sua chegada a São Paulo, procurou adquirir terras e constituir sociedades agrícolas. Em 1807 fundou o Engenho do Limoeiro, em Piracicaba, onde começou a produzir açúcar; em 1814 comprou a fazenda Monjolinho, na mesma cidade, destinada à criação de animais. Estes bens serviram de entrada na sociedade que fez com o Brigadeiro Luiz Antonio de Souza Queiróz, com o objetivo de comprar terras para fabricar açúcar e criar animais. Ainda que a sociedade tenha acabado repentinamente com a morte do Brigadeiro em 1819, Vergueiro continuou se destacando como negociante nas duas áreas econômicas de destaque 
49

RICCI, Magda. Assombrações de um padre regente: Diogo Antonio Feijó (1784-1843). Tese (Doutorado em História). Universidade Estadual de Campinas, Instituto de Filosofia e Ciências Humanas, Campinas, 1998. p.224.

50

CAVALCANTE, Berenice. José Bonifácio: razão e sensibilidade, uma história em três tempos. Rio de Janeiro: Editora FGV, 2001. p.19.

51

MELLO, Evaldo Cabral de. A outra independência. 0 federalismo pernambucano de 1817 a 1824. Rio de Janeiro: Editora 34, 2004.

52

DOLHNIKOFF, Miriam. José Bonifácio. São Paulo: Companhia das Letras, 2012, p.118.

53

Interessante perceber que "o Brasil escolheu [no total] 94 deputados (efetivos e suplentes) para irem a Lisboa, mas (...) somente 45 ocuparam de fato seus assentos nas Cortes." (BERBEL, Márcia Regina. A nação como artefato...0p. Cit., p.80).

54

A Junta Governativa Provisória de São Paulo, levando em consideração sugestões das Câmaras da Província e de eleitores, compôs o documento Lembranças e apontamentos do Governo Provisório da Província de São Paulo para os seus deputados, que são instruções para os deputados que iriam representar São Paulo nas Cortes de Lisboa. na então capitania de São Paulo, chegando a abandonar a advocacia. Por diversas vezes arrematou o dízimo de Piracicaba e o contrato da passagem do Cubatão de Santos, rota de passagem de animais.

No mesmo período em que Vergueiro adquiriu proeminência econômica em São Paulo, Diogo Antonio Feijó também se firmava no cenário paulista. Em 1805, então com 22 anos, vivia em São Carlos e ali ensinava gramática. Já em 1810, era dono de uma chácara na mesma vila, e produzia milho e feijão. A partir de 1817, começava a produzir cana-de-açúcar em um engenho com 12 escravos. ${ }^{49}$ Apesar de não ser dos homens mais ricos da capitania, através de redes de relações que a carreira eclesiástica Ihe proporcionava, conseguiu se destacar como político sendo escolhido para eleitor que iria a São Paulo escolher os deputados às Cortes. Dali saiu eleito para sua primeira grande experiência política.

Como Feijó, os irmãos Andrada também não vinham de uma familia de destaque na capitania paulista. 0 pai, José Ribeiro de Andrada, acumulava funções administrativas que lhe davam certo prestígio: coronel do regimento dos Dragões Auxiliares da capitania de São Paulo, fiscal da Intendência das Minas de Paranapanema (1746), almoxarife da Fazenda Real (1759-64) e escrivão da Junta Real da Fazenda de São Paulo (1768-72). Na lista nominativa de 1765, aparece como coronel e "mercador" residindo na vila de Santos, possuindo bens no valor de oito contos de réis, sendo a segunda maior fortuna da vila. ${ }^{50}$ Antonio Carlos de Andrada e Silva, nasceu em Santos, em 1783, sendo o caçula dos Andrada. Do mesmo modo que seus irmãos, estudou em Coimbra, formando-se em Direito. Voltando ao Brasil atuou em cargos administrativos, como juiz de fora em Santos e ouvidor em Olinda. Nesta vila, teve participação ativa na Revolução Pernambucana de 1817, que objetivava a independência da região. Por sua participação no evento, foi condenado à prisão, de onde saiu quatro anos depois para ocupar o posto de deputado às Cortes por São Paulo. ${ }^{51}$

José Bonifácio de Andrada e Silva, mesmo não tendo sido eleito para as Cortes, desempenhou papel importante na articulação das ideias expressas naquela Assembleia. Bonifácio optou por não ser candidato e, assim, permaneceu na província para atuar à frente da Junta. Cabe dizer que as Lembranças e apontamentos do Governo Provisório da Província de São Paulo para os seus deputados, apesar de ir assinada por todos os integrantes da Junta de São Paulo, foi provavelmente escrita por Bonifácio. ${ }^{52}$

Com exceção de Bonifácio, foram estes os deputados paulistas que, após quase dez meses de atraso, chegam à capital portuguesa em 11 de fevereiro de 1822, fazendo o juramento e tomando assento no Congresso das Cortes de Lisboa. ${ }^{53}$ Como apontei no início deste texto, são três os pontos principais que a partir de então, com a presença dos paulistas são, passarão a ser debatidos nos próximos oito meses: a busca pela manutenção da unidade, mas exercida através de um poder executivo no Brasil; debate em torno de qual seria o centro de poder na América portuguesa; e o livre-comércio. Estas três questões já estavam presentes nas Lembranças e apontamentos do Governo Provisório da Província de São Paulo para os seus deputados ${ }^{4}$ e os paulistas se esforçaram para defendê-las. Até porque as ideias ali expostas não foram bem recebidas pelos portugueses, sendo motivo de constantes ataques quando da sua apresentação nas Cortes, no dia 6 de março de 1822. 
Diário das Cortes, 11 de fevereiro, p.147, grifos meus. Disponivel em: http://debates.parlamento. pt/catalog.aspx?cid=mc.c1821. Consultado em $15 / 03 / 2011$.
Vide NEVES, Lucia Maria Bastos P. das. Cidadania e participação politica na época da Independência do Brasil. Caderno Cedes, Campinas, v.22, n.58, 2002.

57

Diário das Cortes, 1 março, p.352.
Cortes: reciprocidade e autonomia econômica

Os paulistas chegaram às Cortes determinados a defender a igualdade entre brasileiros e portugueses e Antonio Carlos foi um dos primeiros e mais contundentes a apresentar esta ideia. Já em sua primeira participação, em 11 de fevereiro, o deputado apresentou algo que seria defendido ao longo das próximas reuniões: fala em separação, caso não houvesse igualdade entre brasileiros e portugueses. 0 contexto era a discussão sobre a relação entre Brasil e Portugal:

\begin{abstract}
A respeito de dizer-se, que os povos apesar de gozarem os mesmos direitos não hão de ter todos as mesmas comodidades, digo, que se isto assim fosse, a nossa união não durava um mês; os povos do Brasil são tão portugueses, como os povos de Portugal, e por isso hão de ter iguais direitos. Em quanto a força dura, dura a obrigarão de obedecer. A força de Portugal há de durar muito pouco; e cada dia há de ser menor, uma vez que se não adotem medicas profícuas, e os Brasileiros tenhão iguais comodidades. Voto por tanto pelo aditamento. ${ }^{55}$
\end{abstract}

Claro que deputados portugueses reagiram no mesmo nível. 0 deputado português Francisco Trigoso aumentou o tom, argumentando que Portugal e Brasil lucrariam se continuassem unidos. Um argumento, aliás, que será repetido incansavelmente por diversos deputados, inclusive pelos deputados paulistas, até o fim. A variação do termo "recíproco" e "reciprocidade" aparecem 67 vezes entre 11 de fevereiro a 10 de outubro, quase sempre ligado às relações comerciais entre Portugal e Brasil, saída da boca de deputados portugueses e brasileiros. A presença destes e outros conceitos que atravessavam o atlântico são sintomáticos para se perceber 0 afluxo de ideias debatidas pelos dois lados interessados. As diversas ideias apresentadas pelos paulistas nas Cortes já tinham viajado bastante, fazendo com que os deputados brasileiros estivessem de antemão preparados para os argumentos portugueses. Isso ocorria pela circulação de correspondência entre parentes e parceiros de negócios, além de jornais e panfletos, acelerando a transmissão de informações. ${ }^{56}$

Dois dias depois da chegada dos deputados de São Paulo, Antonio Carlos apresentou um dos pontos vitais do projeto paulista: a questão de um braço do executivo em terras brasileiras. Vergueiro, em sua primeira intervenção, descontente com o rumo das discussões naquele dia, deixa claro a que ponto chegariam as propostas da bancada paulista. Segundo ele, "o Brasil está pronto a unir-se com Portugal, mas não segundo a marcha que leva o Congresso." Apesar desta estocada, o próprio Vergueiro utilizaria o argumento da reciprocidade dos dois reinos como algo essencial. ${ }^{57}$ Mais tarde, a 6 de março, ele levantaria furor nos deputados portugueses ao aprofundar esta questão nos seguintes termos:

\footnotetext{
0 Brasil não se sujeita com argumentos; ha de sujeitar-se por uma vontade espontânea, fundada sobre o interesse recíproco dos dois Reinos. Uma vez que não se entenda assim, seguramente deve obrar a força da desunião, estabelecida pela natureza: para a vencer são necessários vínculos muito fortes; estes vínculos são o interesse recíproco. 0 Brasil quer a união, e desde o principio a proclamou; e até por não excitar desconfiança, deixou de exigir cautelas, e prestou todos os atos de adesão à causa comum, entendendo que os ilustres Representantes de Portugal não abusarão desta confiança, para Ihe impor um jugo pesado. ${ }^{58}$
}

Para azedar as relações entre deputados dos dois reinos, no dia 22 de março é posta à mesa de discussão uma representação de São Paulo. Esta 
Em uma espécie de "wikileaks" metropolitano, a Corte de Lisboa tem acesso à esta carta enviada pela Junta Provisória governativa de São Paulo à D. Pedro. Se trata da "Representação ao príncipe", de 31 de dezembro de 1821. CALDEIRA, Jorge. José Bonifácio de Andrada e Silva. São Paulo, Editora 34, 2002. p.134-137.

60

Diário das Cortes, 22 de março, p.577.

61

Ibidem, p.578 representação, em seus pontos principais, conclamava D. Pedro a permanecer no Brasil e já adiantava a união entre paulistas e fluminenses; falava nos sentimentos de independência dos nascidos neste reino; apontava os paulistas como "os primeiros que ousam levantar sua voz e protestar contra atos inconstitucionais"; condenava o andamento de um projeto nas Cortes, onde "se descobre o maquiavelismo com que, com douradas cadeias, se intenta escravizar este riquíssimo pais, e reduzi-lo a mera colônia"; defendia a opção por um centro comum de governo no Brasil e; enfim, dava claras mensagens de que poderia haver luta, já que os paulistas "preferiam a morte à escravidão, [e estavam dispostos a] não pouparem sacrificios até esgotarem a última pinga de seu sangue, para sustentarem seus direitos" 59 .

A representação, como era de se esperar, não foi bem recebida. Segundo o deputado português José Joaquim Moura, tratava-se de um "crime de rebelião", e excedendo "todas as medidas da insolência, da anarquia, e da rebelião e que não pode haver coisa mais inconstitucional nem mais oposta à desejada união de Portugal com o Brasil." Afirmação que recebe 0 apoio de muitos deputados presentes no Congresso. ${ }^{60} 0$ deputado baiano Luis Paulino de Oliveira Pinto da França é rápido em esclarecer que esta não é a posição de todas as províncias do Brasil, já que a carta "declara que aquela é a vontade da província, e afiança que esta vontade existe unida à da do Rio de Janeiro"61

Pinto França toca num ponto crucial do projeto paulista, qual seja a opção pelo Rio de Janeiro como centro de poder. Esta opção, certamente estava relacionada à proeminência que o Rio adquiria desde a transferência da Corte, em 1808. Para István Jancsó,

ao sediar a Corte, o Rio de Janeiro torna-se, de fato, o pólo articulador da diversidade constitutiva na América Portuguesa, realizando o papel que antes cabia ao Reino Peninsular. Para ele passaram a convergir os canais de poder, tanto do judiciário quanto do executivo, produzindo uma intensificação da troca de experiência e prática política de magnitude anteriormente impensável para os coloniais.

A experiência administrativa se intensificou ainda mais com a elevação do Brasil à categoria de Reino em 1815. Assim, abrir mão do acúmulo de poder político que os brasileiros haviam adquirido em favor de Portugal estava fora de cogitação. ${ }^{62}$

Não há, entretanto, como menosprezar o peso que tinha para os

JANCSÓ, István. A construção dos estados nacionais na América latina - apontamentos para o estudo do império como projeto. IN: SZMRECSÁNYI, Tamáz; LAPA, José Roberto do Amaral (orgs). História econômica da Independência e do Império. São Paulo: Hucitec/ Associação Brasileira de Pesquisadores em História Econômica/ Editora da USP/ Imprensa Oficial, 2002. p.22-25. paulistas as ligações mercantis que haviam se estabelecido entre São Paulo e o Rio de Janeiro, desde o final do século XVIII, mas que se fortaleceram a partir de 1808. Em estudo acerca das relações de mercado entre liberais no Rio de Janeiro, Cecília Helena de Salles Oliveira percebeu como as questões econômicas influenciavam na maneira como era conduzida a política na província fluminense. Analisando o grupo liderado por Joaquim Gonçalves Ledo, Januário da Cunha Barbosa e José Clemente Pereira, a autora demonstra como a dinâmica do mercado articulava interesses econômicos das três principais províncias do centro-sul: São Paulo, Minas Gerais e Rio de Janeiro. 0 abastecimento do mercado carioca era realizado por negociantes e proprietários do sul de Minas e de São Paulo. Enquanto os mineiros traziam animais vindos do Mato Grosso e Goiás, os paulistas iam até a região do Rio da Prata buscar gado. Assim, as relações comerciais eram estabelecidas em cadeias até Montevidéu e Buenos Aires, através de 
OLIVEIRA, Cecilia Helena de Salles. Astúcia liberal... Op. Cit.

64

Ibidem, nota 273 .

65

MARCONDES, Renato Leite. Formação da rede regional de abastecimento do Rio de Janeiro: a presença dos negociantes de gado (1801-1811) Topoi, Rio de Janeiro, p.59, mar.2001; PETRONE, Maria Thereza Schorer. O barão de Iguape. Op. Cit.

66

DOLHNIKOFF, Miriam. Elites regionais e a construção do Estado Nacional. In: JANCSÓ, István. (org.). Brasil: formação do Estado e da Nação. Op. Cit., p.433.

67

MELLO, Evaldo Cabral de. Op. Cit., p.14.

68

Diário das Cortes, 13 de fevereiro de 1822, p.175. diversos contatos ao longo do caminho, com algumas exceções de grandes negociantes que conseguiam ampliar sua rede de negócios por todo o conhecido Caminho do Viamão, a estrada que integrava toda a região sul. ${ }^{63}$ Um exemplo de comerciante que possuía conexões desde o Rio de Janeiro até Montevidéu era João Soares Lisboa, ligado ao grupo liberal de Ledo. Conta-nos a autora que ele possuía matrícula na Junta do Comércio do Rio de Janeiro como negociante de "grosso trato", e entre 1820 e 1821 possuía concessão para "suprir de víveres o Exército pacificador" em Montevidéu. Até 1821 morou no Rio Grande do Sul. ${ }^{64}$

Os paulistas obtinham grandes lucros com a negociação de animais vindos do Sul para o Rio de Janeiro, principalmente após a chegada da corte portuguesa. Antonio da Silva Prado era um empresário que fazia a conexão entre os negociantes sulinos com a praça carioca. Prado, em 1818, percebendo a necessidade de mais gado no Rio de Janeiro escreve a João da Silva Machado pedindo conselhos acerca deste mercado. Esta relação acaba por se transformar em uma grande sociedade, onde Machado comprava gado nos limites da América portuguesa, indo até Buenos Aires e Montevidéu, deixando a negociação final com Prado, que de São Paulo encaminhava as tropas para o Rio. ${ }^{65}$

Ficam, assim, evidentes as conexões entre motivações econômicas e posições políticas relativas à aproximação dos paulistas com o Rio de Janeiro, apesar do discurso por autonomia provincial por parte dos paulistas nas Cortes. A ideia de uma federação, que aparece subentendida nos discursos dos deputados paulistas, deve ser mesurada com o contexto econômico das províncias do centro-sul brasileiro. 0 federalismo "puro' (se tal coisa existe), segundo definição de Miriam Dohlnikoff, baseada em Preston King, seria "um arranjo institucional adotado como estratégia de construção do Estado, cuja principal característica é a coexistência de dois niveis autônomos de governo (regional e central) definidos constitucionalmente".66 Já o federalismo defendido pelos pernambucanos, desde 1817,

pretendia que a soberania revertesse às províncias, as quais podiam negociar um pacto constitucional, e, caso este não lhes conviesse, usar de seu direito a constituírem-se separadamente, sob o sistema que melhor lhes parecesse. ${ }^{67}$

Por outro lado, o que aparece subjacente nos discursos dos paulistas nas Cortes é um federalismo em que a união das partes da monarquia portuguesa estaria condicionada à associação de "corpos heterogêneos", isto é, a associação não poderia basear-se na igualdade entre as partes, pois cada uma delas necessitava de legislação específica. Neste sentido, cabe atentarmos para o debate em torno do projeto de suspensão dos magistrados. Antonio Carlos defendia que se devia conceder "ao Brasil uma autoridade com o poder de suspender os magistrados nas causas de queixas".68 $\mathrm{Na}$ continuação de sua argumentação, comparando o Brasil com Estados Unidos da América e o Reino da Suiça, o deputado paulista enfatizava que o Reino de Portugal era formado por dois povos e que o arranjo político devia respeitar a especificidade de cada um. Com isso ele estava apontando para uma igualdade entre os povos do Brasil e de Portugal.

Esta argumentação era encontrada já nas propostas das Lembranças e apontamentos, preparadas antes da chegada dos paulistas a Lisboa, que em seu capítulo 1, artigo 4, define a nação portuguesa como constituída pelos Reinos de Portugal e do Brasil. No capítulo II, artigo 2, propõe que 
Lembranças e apontamentos do governo provisório da província de São Paulo. Rio de Janeiro: Typographia nacional, 1821. Cap. II, artigo 2.

70

Diário das Cortes, 25 de abril de 1822, p.953.

71

Fala de Borges de Barros, Diário das Cortes, 6 de março de 1822.

72

Diário das Cortes, 22 de março, p.581; p.596.

ALEXANDRE, Valentim. Os sentidos do Império: questão nacional e questão colonial na crise do Antigo Regime portugês. Porto, Afrontamento, 1993. p.587-593. vintismo: economia política e política econômica nas Cortes Constituintes. Analise social, vol. XXVI, p.5, 1991.

se "parece conveniente que se estabeleça um governo geral executivo para o reino do Brasil, a cujo governo central estejam sujeitos os governos provinciais, determinando-se os limites dessa subordinação." ${ }^{69}$ Em vista da argumentação levantada pelos paulistas, mesmo sem mencionar o termo federalismo, ficava claro que seu projeto compreendia o Império português formado por partes autônomas e heterogêneas e cada qual devia possuir seu arranjo político próprio.

Assim, aproximava-se do projeto defendido pelos liberais cariocas, que se fundamentava na primazia do poder legislativo e no estabelecimento do mercado interno. Com isso, proprietários e negociantes com interesses estabelecidos no centro-sul seriam arregimentados em torno dessa ideia.

Apesar de paulistas falarem que "cada província se governa hoje independente"70, e baianos concordarem, "as províncias do Brasil podem chamar-se reinos"71, as ideias quanto a maneira de conduzir a autonomia eram divergentes entre paulistas/fluminenses, baianos e pernambucanos. Os próprios deputados portugueses perceberam que havia divergências entre as províncias, atacando argumentos presentes na Representação como vindo de "facciosos, e rematados loucos da junta de S. Paulo"72.

Entretanto, após o discurso de Feijó em 25 de abril, começa a se abrir espaço para convergência de interesses entre paulistas e os deputados do nordeste. Isso se reforçava nas discussões sobre as medidas econômicas, principalmente no que tocava a defesa do livre-comércio e a abertura dos portos. Assim, entramos no último ponto da pauta paulista: as relações comerciais entre Brasil e Portugal. Este tema tomará grande parte das discussões até a saída da delegação paulista.

Com relação à questão das relações comerciais, deve-se salientar que mesmo entre os deputados portugueses não havia coesão de ideias. Analisando os discursos nas Cortes, Valentim Alexandre divide os deputados em dois grupos antagônicos: a ala mais radical, encabeçada por Fernandes Tomaz, "integracionista", entendendo Portugal e Brasil como nações integradas; e a ala composta pelos "conciliadores", liderados por Borges Carneiro, que propunha uma certa negociação de autonomia com o Brasil, desde que se preservasse a integração econômica. ${ }^{73}$

Os integracionistas, portanto, apresentavam-se em termos bastante fortes para defender a dignidade da nação portuguesa, que se consubstanciava na preservação do regime constitucional e na garantia da hegemonia portuguesa no sistema luso-brasileiro. A explosão de Fernando Tomaz na sessão de 22 de março, após a leitura da Representação da Junta de São Paulo, dizendo "passe o Sr. Brasil muito [bem]", estava exprimindo o problema principal na união dos dois reinos, vigente desde 1808, que estava funcionando em desvantagem para Portugal. Assim, sua defesa da nação portuguesa utilizava-se de argumentos caros ao pensamento econômico da época, conhecido como "patriotismo mercantil." ${ }^{74}$ José Luis Cardoso assinala que "a legislação econômica produzida durante o periodo vintista indicia ações de política econômica de natureza marcadamente protecionista. A proibição de importações ou a fixação de elevados direitos de entrada foram regras comumente adotadas, tendo em vista a recuperação dos sectores de atividades ameaçados pela concorrência estrangeira." ${ }^{75}$

Os mais interessados nas restrições aplicadas ao livre comércio eram aqueles que formavam o grupo mercantil da praça de Lisboa e do Porto. Eram comerciantes e industriais que vinham perdendo espaço na praça mercantil do Rio de Janeiro. São os interesses desses indivíduos que são 
76

Essa comissão foi formada por deputados portuguêses e brasileiros, sendo composta por: Antonio Carlos e Vergueiro, por São Paulo; Gonçalves Ledo, pelo Rio de Janeiro; Vieira Belford, pelo Maranhão; Marques Grangeiro, por Alagoas; e Almeida e Castro, por Pernambuco. Os portugueses foram Ferreira Moura, Trigoso, José Antonio Guerreiro, Anes de Carvalho, Borges de Carneiro e Pereira do Carmo. Ver ALEXANDRE, Valentim. Op. Cit., p.614.

77

Diário das Cortes, 18 de março, p.533.

78

Diário das Cortes, 15 de fevereiro, p.506.

79

Diário das Cortes, 15 de fevereiro, p.506; ALEXANDRE, Valentim. Op. Cit., p.631. defendidos pelos deputados integracionistas nas Cortes quando se tratam de questões econômicas. Neste sentido, a conclusão dos trabalhos da Comissão para cuidar dos negócios do Brasil, composta em 12 de março e apresentada aos deputados em 18 de março ${ }^{76}$, se foca na discussão do decreto sobre as relações comerciais entre Portugal e Brasil, já que estas relações representavam "um dos mais fortes vínculos da união", e primavam pela "perfeita igualdade e reciprocidade"77. Anteriormente, já havia sido formada uma comissão especial para as relações luso-brasileiras que apresentou seu parecer em 15 de fevereiro. Este parecer, apoiado na opinião dos negociantes de Portugal, propunha alteração no regime mercantil luso-brasileiro, que desde a abertura dos portos vinha deixando um saldo negativo na balança comercial portuguesa. ${ }^{78} 0$ documento, produzido como base nas informações dos comerciantes portugueses trazia a ideia da nação portuguesa como um mercado único, integrado e protegido do exterior. ${ }^{79}$ É neste parecer que se encontra a base para o parecer de 18 de março da Comissão que tratava dos negócios do Brasil.

Entretanto, os brasileiros da Comissão (principalmente Antonio Carlos e Lino Coutinho) atacaram firmemente algumas partes do projeto, vendo nelas uma tentativa de restabelecer a supremacia portuguesa sobre a economia brasileira. A partir de então, em 1 de abril, o debate se concentrou em três pontos principais: a reserva do comércio de cabotagem à marinha nacional; o exclusivo concedido no mercado brasileiro ao sal e aos produtos vinícolas portugueses; e a livre admissão dos artigos industriais da antiga metrópole no Brasil. Os portugueses retornam ao argumento das causas da crise econômica luso-brasileira. Como diz Borges Carneiro, o

lamentável decreto de 28 de janeiro de 1808 [que] franqueando os portos do Brasil a todas as fazendas estrangeiras arruinou Portugal, e o Brasil mesmo, se excetuarmos um momentâneo bem da agricultura, nada prosperou, e viu-se até então fundaremse nas costas boas casas, e dali em diante deixou de se ver.

0 Andrada contra-argumenta qualquer protecionismo por parte do "patriotismo mercantil" português, discorrendo sobre o livre-comércio, mostrando como este favoreceu a América, fazendo com que ela tenha prosperado desde 1808:

0 fato é que todas as Nações, que tem admitido o comércio livre tem prosperado, e o dizer-se o contrario, é um erro, desmentido pela historia política e comercial de todo o mundo. 0 Brasil é um exemplo da força destes princípios. Algumas das suas províncias, como a da Bahia, que exportavam $25 \$$ caixas de açúcar, hoje exportam o dobro. Igual sorte teve a província de S. Paulo, na qual tem quase dobrado as suas produções depois da franqueza do comércio. E ao mesmo tempo, que pelo comércio livre aumentou-se a produção, diminuiu o preço das mercadorias importadas, a ponto que o ferro por exemplo baixou de 409 réis o arrate a 40 réis. 0 decênio de 8 de Janeiro de 1808 infeliz para Portugal foi o avesso para o Brasil, foi a fonte da sua atual prosperidade e continuará a ser o estimulo maior da sua progressiva riqueza.

É extremamente interessante que Antônio Carlos utiliza o exemplo do açúcar, especialmente se lembrarmos de como os grandes negociantes em São Paulo, alguns deles citados neste trabalho, começaram a investir seriamente em açúcar.

E sobre a navegação de cabotagem, logo à frente em seu discurso ele se refere nestes termos: 
80

Diário das Cortes, 9 de abril, p.724.

81

OLIVEIRA, Cecilia Helena de Salles. Astúcia Liberal... Op. Cit., p.187.

82

Diário das Cortes, 9 de abril, p.727.

83

Diário das Cortes, 15 de abril, p.807.

84

Valentim Alexandre realizou uma excelente pesquisa utilizando balanças comerciais portuguesas, demonstrando saldos da economia de Portugal entre 1808 a 1822 . Suas conclusões são muito interessantes, mas fogem dos parâmetros deste trabalho apresentá-las. Diga-se de passagem, que a quebra da principal praça portuguesa, Lisboa, excede os $90 \%$ no período de 1808 até 1831. ALEXANDRE, Valentim. Op. Cit., Parte VI.

85

ALEXANDRE, Valentim. Op. Cit. p.774.
Os princípios gerais são, que limitar a distribuição das mercadorias a poucas mãos, é criar em favor dele um monopólio, o que faremos permitindo só aos nossos navios o comércio de cabotagem, a conseqüência desse monopólio seja o alteamento dos gêneros navegados por nós somente, e o resultado o empobrecimento gradual dos consumidores. ${ }^{80}$

Para o Andrada, opiniões como a de Borges Carneiro tendiam a enfatizar o bem de negociantes individuais ao invés do bem do comércio em geral. Estes negociantes (aqui ele está falando dos da praça mercantil de Lisboa e do Porto) atuariam com um monopólio, o que seria prejudicial ao livre-comércio. Na imprensa fluminense, entre janeiro e maio, os liberais consideram os "monopolistas de Lisboa e Porto" e os "fabricantes" portugueses de vinhos e tecidos como seus principais adversários, por defenderem a "opressão colonial" e o "absolutismo"81.

0 deputado baiano Cipriano Barata, com argumentos retirados dos últimos estudos da economia política, ainda defende que o comércio de cabotagem feito somente por Portugal estaria estrangulando a grande oferta de produtos agrícolas do Brasil, já que aquela nação possuia um comércio ainda reduzido se comparado com a capacidade brasileira. ${ }^{82}$

Apresentando números, Antonio Carlos aponta o desequilíbrio comercial entre Brasil e Portugal ${ }^{83}$, argumentando que palavras como "exclusivo" deveriam ser riscadas do dicionário e que reciprocidade - um tema bastante retomado pelos portugueses - para o paulista não passava de ficção. Cita o exemplo do açúcar com o qual, segundo ele, nenhuma outra nação podia competir em produção e que era um modelo de desequilíbrio no comércio entre Brasil e Portugal.

De mais Portugal oferece um fraco mercado aos gêneros do Brasil: apenas 16000 caixas de açúcar são anualmente importadas do Brasil para aqui, e nestas se incluem as que se reexportam para Espanha; no Brasil porém gastam-se anualmente de vinho português quase tanto como o que se exporta para todas as nações da Europa juntas: no ano de 1819 gastou o Brasil 21:088 pipas de vinho portugues, e no de 1820, nos primeiros seis meses, 18:505. Ora que é 16:000 caixas [de açúcar] para a safra do Brasil, que anda por algumas 200:000 [caixas]?

De fato, no início do século XIX, a economia brasileira superava a de Portugal, sendo que a maioria das exportações portuguesas anteriores a 1808 era constituída de produtos brasileiros reexportados.

A grande insistência portuguesa em relação ao decreto da abertura dos portos se explica pela crise que Portugal vinha passando em decorrência dessa ação. ${ }^{84}$ Entretanto, o problema comercial entre Brasil e Portugal, que aprofundou a crise, residia na quebra dos preços dos produtos coloniais (1819) e na perda de tráficos por parte de Portugal. Isto teria sido sentido como maior impacto na década de $1820 .{ }^{85}$ Assim, o que na verdade está subjacente ao discurso português quando se refere a 1808, é a perda do papel de entreposto dos gêneros coloniais brasileiros, que antes eram revendidos com ampla margem de lucro. Outras nações, com as primeiras tentativas de comércio direto com o Brasil, acabaram por formar novas redes de relações mercantis, que eliminavam a função de Portugal como intermediário. Com estas novas rotas de negócios surgia a necessidade de desenvolver um grande porto de saída, o que o Rio de Janeiro supriria a contento, transformando esta cidade atrativa aos olhos da elite econômica e da elite política, que eram compostas pelas mesmas pessoas. 
86

OLIVEIRA, Cecília Helena Salles. Astúcia Liberal... Op. Cit., p.159.

87

Ibidem, p.161.

Os deputados cariocas foram: Custódio Gonçalves ledo, irmão de Joaquim Gonçalves Ledo, era médico no Porto e envolveu-se com o movimento liberal ali; D. Francisco Vilela Barbosa, militar ligado à Universidade de Coimbra; Luis Martins Basto, comerciante em Coimbra; João Soares de Lemos Brandão, bacharel em leis e Luis Nicolau Fagundes Varela, poeta; estes dois últimos residiam no Rio de Janeiro. BERBEL, Márcia Regina. A nação como artefato... Op. Cit., p.71.

89

Lembranças e apontamentos... Op. Cit., cap. II item 9.
Os argumentos do "patriotismo mercantil" foram amplamente combatidos pelos deputados paulistas, mas deve-se levar em consideração que eles mesmos não pensavam de maneira tão diversa dos seus colegas portugueses quanto aparentam em seus discursos. Na luta contra um inimigo comercial comum, os britânicos, a união protecionista era bem vista e necessária. Os argumentos dos liberais brasileiros, expressos nos jornais fluminenses, eram de que, ao mesmo tempo em que se suprimisse qualquer restrição à livre concorrência, deveria erigir-se tarifas alfandegárias protecionistas para a produção local e o governo precisaria garantir investimentos e até subsidiar a produção. Como aponta Cecília Helena de Salles Oliveira, "o projeto que construiram conciliava, contraditoriamente, práticas liberais e práticas protecionistas".86 Neste sentido, a palavra mais utilizada nas Cortes dava seu ar da graça nas bocas brasileiras: "reciprocidade".

Mas a conciliação de interesses dos brasileiros com os liberais portugueses estava relacionada a uma defesa frente ao comércio inglês. Os fluminenses viam no mercado português um grande consumidor dos produtos cariocas e, além disso, aquele mercado serviria "como trampolim para a entrada da produção fluminense aos mercados europeus, sem a mediação de negociantes britânicos". Assim, ocorria um reajustamento das relações entre Brasil e Portugal passando pela expansão dos interesses no mercado interno português, exatamente o que ambicionavam os portugueses com relação ao mercado brasileiro. Os liberais fluminenses viam nos vínculos mercantis com Portugal uma "extensão do comércio de cabotagem, e a livre circulação de mercadorias entre os dois Reinos, aparentemente, garantia a 'reciprocidade' sob a qual proprietários e negociantes fluminenses poderiam ampliar as bases dos empreendimentos que realizavam" ${ }^{17}$.

Estas ideias apareciam defendidas em jornais liberais cariocas, mas nas Cortes de Lisboa foram os paulistas os seus maiores defensores. É realmente um fato importante de se destacar: os liberais fluminenses que não foram às Cortes, como Joaquim Gonçalves Ledo, Clemente Pereira e Manuel Joaquim da Silva Porto, eram extremamente combativos na defesa dos seus pontos de vistas. Já os deputados fluminenses presentes nas Cortes, pouco falaram após a chegada dos paulistas. Segundo alguns autores, havia um desinteresse dos fluminenses pelas Cortes, pois os que possuiam interesses no Rio de Janeiro e residiam ali preferiam não se afastar da cidade, devido à indefinição da situação carioca. Assim, a banca fluminense em Lisboa era formada por uma maioria de residentes em Portugal, os quais, portanto tinham mais interesses na própria metrópole. ${ }^{88}$

Assim, entre a saída dos paulistas de sua terra natal e os primeiros debates nas Cortes, verificou-se uma mudança de pensamento, levantando "uma dúvida de qual seria o centro de poder na América Portuguesa". Note-se que no documento escrito pela junta de São Paulo, Lembranças e apontamentos, produzido antes da viagem dos deputados a Portugal, no capitulo referente aos "Negócios do Reino do Brasil", o item 9ªtestava que seria "muito útil que se levante uma cidade central no interior do Brasil para assento da Corte ou da Regência (...)".89 Nota-se, portanto, que algo mudou na mente e nos discursos dos deputados paulistas nas Cortes, que passaram a defender a permanência do centro político no Rio de Janeiro. Esta mudança, certamente, estava alicerçada nos interesses econômicos dos paulistas. 
90

Publicado no Correio Braziliense e citado por JANCSÓ, István e PIMENTA, João Paulo G. Peças de um mosaico (Ou apontamentos para o estudo de emergência da identidade nacional brasileira). In: MOTA, Carlos Guilherme. (Org.). Viagem incompleta. A experiência brasileira (1500-2000) São Paulo: SENAC, 2000. p.130.

91

HOLANDA, Sérgio Buarque de. A herança colonial - sua desagregação. IN: Idem. (org.) História geral da civilização brasileira. Tomo II, Vol. 1. São Paulo: Difel, 1970. p.13.

92

Diário das Cortes, 17 de Junho de 1822, p.465.

Diário das Cortes, 26 de junho, p.570-751, grifos meus.

94

Diário das Cortes, 23 de março, p.603.

\section{A ruptura}

Deve-se deixar claro que, quando se fala em paulistas/brasileiros e portugueses, não se está pensando em uma contraposição entre estes dois grupos, como se fossem de nacionalidades diferentes, até porque, neste período, ambos faziam parte da nação portuguesa. No manifesto escrito logo após terem abandonado as cortes, os deputados brasileiros se expressaram nos seguintes termos: "desde que tomaram assento no Congresso de Portugal [os deputados brasileiros fizeram-no para lutar] pelos interesses de sua Pátria, do Brasil e da Nação em geral"90. A nação à qual pertenciam era a portuguesa. Portanto, como bem salientou Sérgio Buarque de Holanda "o 7 de setembro vai constituir simples episódio de uma guerra civil portuguesa, e onde se veem envolvidos os brasileiros apenas em sua condição de portugueses do aquém-mar."91

Assim, em meados de junho de 1822, sem horizontes de uma união de Brasil e Portugal de acordo com as ideias portuguesas, uma nova comissão que havia sido formada para formular artigos adicionais à Constituição relativos ao Brasil, apresentou seus resultados. Andrada é o encarregado de relatá-los, dizendo que o estudo encaminhado pela comissão

convenceu-me que o sistema de unidade inteira dos dois Reinos é quase de absoluta impossibilidade: que a legislatura a respeito de certos negócios deve de necessidade ser diversa em cada um dos respectivos Reinos: e que o Poder executivo não pode obrar no Brasil sem uma delegação permanente e ampla; e que todas as suas ramificações devem ser independentes imediatamente de Portugal. ${ }^{92}$

Esta linha de argumentação causou estardalhaço no Congresso das Cortes de Lisboa. Apesar de já terem sido defendidas, estas ideias não tinham sido apresentadas tão claramente como agora. Elas seriam novas dentro do contexto vintista, que seguia as Cortes de Cádiz, que não admitia a ideia de dois Congressos, já "que isto seria fazer um monstro de duas cabeças, e pretender que a árvore da liberdade tivesse dois troncos", segundo explica 0 deputado português Ferreira Girão. Neste mesmo sentido, o deputado Miranda ataca, também, os artigos desta comissão. Para ele "este projeto tende a deitar por terra as Bases que juramos. As ideias que nele se apresentam são ideias da junta de S. Paulo; e é fora de questão, que ele contém o plano de um edifício de arquitetura paulistana"93. 0 deputado parecia estar jogando pra fora algo que devia estar entalado na garganta dos portugueses desde a chegada dos paulistas em fevereiro. De fato, a atenção para com os paulistas, que passaram a defender fortemente a separação, já havia sido levantada desde fins de março e era constantemente repetida. 0 deputado baiano Marcos Antonio fala "que aquelas províncias exigem uma particular atenção e consideração deste Congresso" e a partir daí continua a falar de eventos históricos que ocorreram na província paulista:

pois que os habitantes de $\mathrm{S}$. Paulo foram os primeiros que povoaram o Brasil: eles fizeram os descobrimentos de minas, e outros muitos objetos dignos de toda a atenção: sempre se mostrarão os homens mais valorosos, e até deram as maiores provas de lealdade. Eu vou a referir um fato acontecido quando a nação portuguesa sacudiu os ferros da dominação espanhola. Os habitantes de S. Paulo quiseram aclamar Rei a um homem chamado Amador, e este homem disse que ele não era Rei, que não podia admitir tal titulo, e que o verdadeiro Rei era D. João Duque de Bragança. Ora este ato praticado por Amador é digno da atenção deste Congresso: isto merece que o parecer da Comissão seja atendido, para que estas verdades sejam conhecidas com mais atenção, e se tome a deliberação que seja justa. ${ }^{94}$ 
OLIVEIRA, Cecília Helena de Salles. Astúcia Liberal... Op. Cit., p.179.

96

Diário das Cortes, 23 de março, p.603.

97

ALEXANDRE, Valentim. Op. Cit., p.704-706.
Este fato, da aclamação de Amador Bueno, é relembrado novamente quando D. Pedro discursa em São Paulo. Para os liberais brasileiros, e isso fica evidente nos jornais cariocas como o Revérbero Constitucional fluminense, as Cortes não tinham autoridade para responder questões do mercado interno brasileiro. Isto deveria ser da tutela do governo sediado no Rio de Janeiro. $E$, além disso, os políticos das regiões que se ligavam ao projeto do Rio de Janeiro como centro de poder - São Paulo e Minas Gerais - não aceitavam a separação entre as províncias, o que poderia sinalizar um esvaziamento da autoridade da Corte carioca. Para estes indivíduos, tudo passava por um projeto de integração do mercado interno que deveria ser coordenado a partir da província fluminense. ${ }^{95}$ Mesmo entre os deputados portugueses a percepção da união das províncias do centro-sul era algo sentido. Segundo Trigoso:

\begin{abstract}
os povos do Rio de Janeiro estão em descontentamento conhecido, e o mesmo os das Minas, visto que os Deputados que tinham mandado para o Congresso, retrocederão do Rio de Janeiro; supõe-se que emissários de Minas, e S. Paulo vão unir-se no Rio de Janeiro para fins particulares que tem. A Comissão não pode dizer exatamente que isto haja de suceder, nem pode conhecer quais são especificamente os fins que essa reunião se propõe; mas tendo todas estas noticias elas são suficientes para não poder dar uma absoluta opinião sobre o espirito que ditou esta carta. (...) As provas que há são que existe uma coligação entre as províncias, e que nelas existe descontentamento. ${ }^{96}$
\end{abstract}

Enfim, a discussão não avança mais e, a 26 de Agosto, os deputados paulistas pediram sua saída do Congresso, já que as províncias de São Paulo, Rio de Janeiro, Minas Gerais e outras estavam em "dissidência com Portugal". Mas acabaram tendo que fugir, sem passaporte, para a Inglaterra, em 6 de outubro. ${ }^{97}$

Os três pontos fundamentais que a bancada paulista defendeu - autonomia, a manutenção do Rio de Janeiro como centro do poder e o livrecomércio - estavam ligados aos interesses comerciais de sua província, da mesma forma que os deputados portugueses defendiam os interesses da elite mercantil e industrial de Lisboa. A opção pelo Rio de Janeiro se explicita quando se olha para as conexões mercantis entre as duas regiões, além da ligação administrativa que surge quando da vinda da família real. A raiz explicativa da defesa da autonomia paulista frente às Cortes, passando por uma relação com o Rio de Janeiro, se encontra na compreensão das relações do mercado interno do período colonial, as quais busquei apresentar de maneira inicial. 0 Rio de Janeiro era um mercado consumidor importantíssimo no contexto do Sul, principalmente após 1808, o que levou ao consequente inchaço populacional da província fluminense. Para ali eram trazidos produtos relacionados ao tropeirismo sendo também ponto de saída para outros produtos, como o açúcar, que começava a ser produzido em São Paulo.

0 pedido de saída dos paulistas das Cortes coincide (se tal palavra pode ser aplicada no contexto), com a programação da visita de D. Pedro à província de São Paulo. Até então, como vimos no exemplo da "Bernarda", não havia uma homogeneidade política na província. Apesar dos grupos ligados aos Andrada falarem em favor de um centro de poder no Rio de Janeiro, isto não era de aceite comum ali. Mas, D. Pedro, conhecedor da importância do sul para 0 mercado do Rio de Janeiro e ciente de que os problemas políticos na região se originavam nas disputas pelo mercado interno, empreendeu uma viagem para atrair os negociantes e proprietários para seu projeto separatista.

0 governo do príncipe regente já havia condenado a "Bernarda" um mês após o ocorrido, mas anistiou os envolvidos, sabendo da necessidade 
98

BITTENCOURT, Vera Lúcia Nagib. De altezo real a imperador: 0 governo do Príncipe $d$. Pedro, de abril de 1821 a outubro de 1822. Tese (Doutorado em História). Universidade de São Paulo, Faculdade de Filosofia, Letras e Ciências Humanas, São Paulo, 2006, p.307-318.

99

Idem, p.323-324

100

Ibidem, p.349.

101

Ver LYRA, Maria de Lourdes Viana. Memória da independência: marcos e representações simbólicas. Revista Brasileira de História, v.15, n.19, 1995; MALERBA, Jurandir (org.). A independência Brasileira. Novas dimensões. Rio de Janeiro, Editora FGV, 2006, especialmente capítulo cap. 1 .

102

AMARAL, Paulo Bonavides Roberto do Amaral. Textos políticos da história do Brasil. Senado Federal, Brasilia, 2002, vol. 1, p.659-660.

103

BITTENCOURT. Vera Lúcia Nagib. Op. Cit., p.355.

104

OLIVEIRA, Cecilia Helena de Salles. Astúcia Liberal... Op. Cit., p.202. de atraí-los. Como bem percebeu Vera Lúcia Nagib Bittencourt, a afirmação da autoridade de D. Pedro dependia da capacidade de arregimentar a rede de negócios, estabelecida na Corte, mas com ramificações em Minas Gerais, São Paulo e Rio Grande de São Pedro. E para esta face sul da rede, São Paulo assumia posição estratégica. Era um local de passagem de animais que vinham do Rio Grande do Sul e que serviriam para abastecer de transporte, vestimentas e alimentação o centro-sul, e também meio de ligação com negócios em Buenos Aires e Montevidéu. ${ }^{98}$

A importância de São Paulo no mercado de abastecimento do Rio de Janeiro, além de entreposto comercial do gado, era evidenciada pelas ligações comerciais que os paulistas possuiam na província fluminense. A casa comercial do brigadeiro Luis Antonio permaneceu atuante até depois de sua morte, levada adiante por seu sócio Nicolau Vergueiro. Antonio da Silva Prado negociava gado e também vendia açúcar para a Corte. Rafael Tobias de Aguiar era sócio de João Pereira de Almeida e sempre o visitava. ${ }^{99}$

Em 25 de agosto, após 12 dias de viagem, D. Pedro chegou a São Paulo. Como aponta Vera Lucia Nagib Bittencourt, nessa visita ele aparentemente sustentava os interesses partidários de seus ministros, José Bonifácio e Martim Francisco, já que se hospedou na casa do Brigadeiro Manuel Rodrigues Jordão e de seu sobrinho Antonio da Silva Prado, acusados, pelos "bernardistas" de terem sido favorecidos pelos Andrada. ${ }^{100}$

Os eventos que se seguem são sintomáticos da importância que a província paulista assumia nos planos de D. Pedro. No dia seguinte a sua chegada, realiza-se a cerimônia de beija-mão, sinalizando a unificação dos paulistas em torno do príncipe regente. Após uma viagem rápida a Santos, D. Pedro retornou à capital da província no dia 7 de setembro, e à tarde, nas margens do rio Ipiranga, proclamou o rompimento com Portugal. Foi um ato simbólico, que sequer aparece nas Atas da Câmara de São Paulo e em periódicos da época. ${ }^{101}$

A Proclamação D. Pedro I feita em 8 de setembro de 1822, em São Paulo é significativa para compreendermos a conformação das elites do centro-sul em torno do Rio de Janeiro. ${ }^{102}$

Nela, primeiramente, D. Pedro enaltecia a participação paulista no processo de Independência, comentando como os deputados desta região se sobressairam perante as Cortes. Mas também aponta que ocorreram distúrbios na província de São Paulo. Quanto a isso, o príncipe regente prometia justiça e pedia união, afirmando que o Brasil seria governado através de uma "Constituição Liberal e judiciosa". São Paulo, juntamente com Minas Gerais e Rio de Janeiro formava um vértice econômico importantíssimo no período e a unidade do país, tanto política quanto econômica, estava atrelada à participação de paulistas e mineiros na formação da nova nação. Logo após a partida de Sua Alteza, teve início uma devassa para punir os culpados pela "Bernarda". Em poucos dias, em 23 de setembro, a devassa em São Paulo deixou de existir e os culpados foram perdoados, o que demonstrou o peso político e econômico dos envolvidos e seu valor para o encaminhamento da nova Nação. ${ }^{103}$

Já em 3 de junho de 1822, portanto antes mesmo da proclamação acima, havia sido convocada uma "Assembleia geral das províncias do Brasil" pelo príncipe regente, para fazer cumprir sua promessa de uma "constituição liberal e judiciosa". Segundo Cecília Helena de Salles Oliveira, a proposta da criação dessa Assembleia ocorreu "em meio a uma profunda pulverização da autoridade pública e do poder político"104, já que havia contestações em diversas regiões, como o exemplo já estudado da "Bernarda" paulista. Era um período de indefinição das autoridades provinciais e 
105

DOLHNIKOFF, Miriam. José Bonifácio... Op. Cit., p.158.

106

OLIVEIRA, Cecília Helena de Salles. Astúcia Liberal... Op. Cit., p.212-213.

107

Ibidem, p.220

108

PEDREIRA, Jorge Miguel. Economia e política na explicação da independência do Brasil. IN: MALERBA, Jurandir (org.). Op. Cit., p.92.

109

Ibidem, p.93 dos vínculos entre os poderes locais. Para muitos grupos liberais, a Assembleia serviria para ajustar os interesses contraditórios em campos políticos e econômicos. "A Constituinte [...] era um instrumento poderoso, pois oferecia às elites provinciais a possibilidade de participação nas tomadas de decisão do governo do Rio de Janeiro." 105

Porém, neste momento os liberais queriam mais. Peticionavam a liberação do mercado e da terra, ao mesmo tempo em que marginalizavam os setores mais populares. Com o intuito de frear o avanço dos liberais, políticos como José Bonifácio, Nogueira da Gama e Carneiro Leão foram contra a convocação da Assembleia. Em julho de 1822, criou-se, por reivindicação de José Bonifácio, um ministério dos "negócios da Justiça e Eclesiásticos", no qual assumiu Martim Francisco, seu irmão. Isto foi um instrumento importante contra as pretensões dos liberais opositores e fortaleceu as lideranças paulistas ligadas aos Andrada. Esse ministério visava controlar o mercado interno da Corte e da província através da atuação rigorosa da polícia e dos magistrados na aplicação das leis. ${ }^{106}$

A convocação da Assembleia e a declaração da Independência a partir de São Paulo procuravam unir as províncias e impedir também que a Constituição que havia sido jurada pelas Cortes se tornasse uma justificativa de legitimação do poder que os liberais queriam exercer neste período. Isto porque esta Carta, que no momento estava em debate em Portugal, previa reformas que afetariam o mercado interno brasileiro e dava fundamentos jurídicos para a ação de certos liberais fluminenses. Portanto, a declaração da Independência estava ligada a dois pontos principais: a concentração do poder político na Corte e o aprofundamento da liberação do comércio externo das províncias do Brasil, ao abolir o protecionismo de mercado por negociantes atacadistas monopolistas. ${ }^{107}$ Através da intermediação de D. Pedro, construia-se um pacto social, resolvendo, assim, o impasse constitucional.

Dessa maneira, a presença de D. Pedro em São Paulo unificou partidários opostos em torno da idéia de separação, fortalecendo o apoio ao príncipe regente e ao Rio de Janeiro como centro executivo. Nesses periodos turbulentos, a disposição do futuro imperador do Brasil de viajar às províncias de Minas Gerais e São Paulo, representou a reafirmação da aliança entre as três principais economias do século XIX. Economias que ainda necessitavam de uma maior integração e inclusive uma maior unificação política, fato comprovado pelos movimentos autonomistas que surgirão após a Independência.

De fato, aparentemente, o que desembocou na separação do Brasil teve um caráter essencialmente político, como aponta Jorge Miguel Pedreira. 0 desacordo orbitava em torno de questões fundamentais de organização política, como "a questão da sede, ou centro, da monarquia [...] e o reconhecimento do Brasil, e não de suas províncias, como corpo político uno, com dignidade e preeminência suficiente para usufruir de ampla autonomia de governo [...].". ${ }^{108}$ Digo aparentemente porque, como o próprio autor salienta, os "integracionistas" portugueses teriam subestimado que 0 eixo Rio de Janeiro-São Paulo pudesse ter imposto às demais províncias do Brasil suas ideias. ${ }^{109} \mathrm{E}$, como vimos nesse artigo, as bases do acordo em torno do estabelecimento do centro da monarquia no Rio de Janeiro estavam ancoradas nos anseios econômicos das elites das províncias do centro-sul. Às questões políticas, precediam os interesses econômicos, indissociáveis uns dos outros. 0 Brasil por mais alguns anos trilharia o duro caminho da unificação política e econômica, cujas rédeas seriam conduzidas pelos grupos de negociantes e políticos articulados em torno do poder central. 